\title{
MOTIVASI BELAJAR PESERTA DIDIK KELAS VIII DALAM MENGIKUTI PEMBELAJARAN PJOK SECARA DARING PADA MASA PANDEMI COVID-19 DI SMP NEGERI 3 BANYUWANGI TAHUN 2020/2021
}

\author{
Ahmad Altaf ${ }^{1}$, I Wayan Artanayasa² I Ketut Semarayasa $^{3}$ \\ ${ }^{123}$ Universitas Pendidikan Ganesha \\ Jurusan Pendidikan Olahraga \\ Program Studi Pendidikan Jasmani Kesehatan dan Rekreasi \\ Email:ahmadaltaf0203@gmail.com¹, wayan.artanayasa@undiksha.ac.id², \\ ketut.semarayasa@undiksha.ac.id ${ }^{3}$
}

\begin{abstract}
ABSTRAK
Penelitian ini, bertujuan untuk mengetahui motivasi belajar peserta didik kelas VIII dalam mengikuti Pembelajaran PJOK secara daring pada masa pandemi COVID-19 di SMP Negeri 3 Banyuwangi tahun 2020/2021. Penelitian ini menggunakan rancangan deskriptif kuantitatif, jenis penelitian survey. Populasi dalam penelitian ini adalah peserta didik kelas VIII di SMP Negeri 3 Banyuwangi yang berjumlah 235 orang. Sampel penelitian ini menggunakan teknik non-random sampling yang dilakukan dengan cara quota sampling dengan besaran $30 \%$ dari total populasi sehingga jumlah sampel dalam penelitian ini adalah 70 orang. Data dianalisis menggunakan statistik deskriptif kuantitatif dengan kategori interval. Hasil dari penelitian ini, menunjukkan bahwa motivasi belajar peserta didik kelas VIII dalam mengikuti pembelajaran PJOK secara daring pada masa pandemi COVID-19 di SMP Negeri 3 Banyuwangi, yakni dari 70 peserta didik yang dijadikan sebagai sampel muncul empat jenis tanggapan terhadap 20 pernyataan dari masing-masing indikator yang dikembangkan dari dua faktor yakni faktor intrinsik dan faktor ekstrisnsik. Pada faktor instrinsik, dengan total jumlah pernyataan 12 akumulasi data yang diperoleh dalam bentuk skor rata-rata yakni 56,80 kategori baik. Sedangkan, pada faktor ektrinsik, dengan total jumlah pernyataan 8 akumulasi data yang diperoleh dalam bentuk skor rata-rata yakni 57,06 kategori baik. Jadi, jika kedua data tersebut dikonvensikan pada tabel interval kategori, diperoleh hasil 64,5 kategori sangat baik, sehingga pembelajaran PJOK yang dilakukan secara daring selama pandemi covid-19 mampu menumbuhkan motivasi peserta didik baik dari faktor dalam (intrinsik) yakni kesehatan, perhatian, minat, dan bakat maupun dari faktor luar (ekstrinsik) yakni metode mengajar, alat pelajaran, dan kondisi lingkungan.
\end{abstract}

Kata-kata Kunci : Motivasi, Pembelajaran Daring, Pembelajaran PJOK, dan Pandemi Covid-19

\begin{abstract}
This study aims to determine the learning motivation of class VIII students in participating in online PJOK learning during the COVID-19 pandemic at SMP Negeri 3 Banyuwangi in 2020/2021. This study used a quantitative descriptive design, survey research type. The population in this study were 235 class VIII students at SMP Negeri 3 Banyuwangi. The sample of this study used a non-random sampling technique which was carried out by means of quota sampling with a size of $30 \%$ of the total population so that the number of samples in this study was 70 people. Data were analyzed using quantitative descriptive statistics with interval categories. The results of this study indicate that the learning motivation of class VIII students in participating in online PJOK learning during the COVID-19 pandemic at SMP Negeri 3 Banyuwangi, namely from 70 students who were used as samples, four types of responses appeared to 20 statements from each of them. each indicator is developed from two factors, namely intrinsic factors
\end{abstract}


and extrinsic factors. In the intrinsic factor, with a total number of statements of 12 accumulated data obtained in the form of an average score of 56,80 good categories. Meanwhile, for extrinsic factors, with a total number of statements of 8 accumulated data were obtained in the form of an average score of 57,06, good categories. So, if the two data are converted to the category interval table, 64,5 category results are very good, so that online learning during the Covid-19 pandemic is able to motivate students both from internal (intrinsic) factors, namely health, attention, interests, and talents as well as from outside factors (extrinsic) namely teaching methods, learning tools, and environmental conditions.

Key words: Motivation, Online Learning, Learning PJOK, and the Covid-19 Pandemic

\section{PENDAHULUAN}

Berbagai problematika dihadapi pada tahun 2020. Salah satu yang sangat anarkis sat ini adalah penyakit COVID-19. Corna virus disease 2019 merupakan penyakit yang disebabkanoleh virus baru, yaitu Severa Acute Respirator Syndrome Coronavirus-2 yang disingkat SARS-Cov-2. COVID-19 berasal dari Wuhan, Tiongkok. Transmisi virus dari penyakit ini dapat menular dari manusia ke manusia (Relman dalam Yuliana, 2020:188).

Negara Indonesia terdampak penyakit COVID-19 pada awal bulan Maret tahun 2020. Penyebarannya yang sangat cepat dapat menimbulkan problematika baru, yang mengakibatkan terjadinya perubahan positif maupun negative dalam berbagai sektor, seperti ekonomi dan pendidikan. Keduanya menjadi trending topik diberbagai media, karena pada kenyataannya ekonomi Indonesia yang mulanya stabil kini berubah derastis begitu juga dalam pendidikan yang biasanya dilakukan secara tatap muka kini beralih menjadi belajar di rumah saja. Peralihan sistem pembelajaran dari tatap muka menjadi belajar dirumah saja, tentu sudah dipikirkan secara matang oleh pemerintah guna mencegah penyebaran penyakit COVID-19.

Oleh karena itu pemerintah menyiasatinya dengan cara memanfaatkan media elektronik dan jejaring internet atau yang disebut pembelajaran daring.

\section{KAJIAN TEORI Motivasi}

.Motivasi adalah hal penting yang berada pada tingkatan pertama dalam asas belajar motivasi berasal dari kata "motif" yakni usaha mendorong seseorang untuk melakukan sesuatu. Banyak pengertian mengenai motivasi, Wlodkwosky (dalam Sugiharto dkk, 207:78) mendefinisikan motivasi sebagai suatu keadaan yang menimbulkan perubahan perilaku. Motivasi juga merupakan perubahan sikap seseorang yang ditandai dengan munculnya rasa atau feeling (Donald dalam Amaludin, 2012:8). Pendapat keduanya disempurnakan oleh Slameto (2003:170) yang menyatakan bahwa motivasi merupakan sebuah proses dalam menentukan konsistensi, intensitas, dan tingkah laku manusia.

Dari pandangan beberapa ahli di atas, maka dapat disimpulkan bahwa motivasi merupakan sebuah dukungan yang menyebabkan terjadinya sebuah perubahan karena adanya tujuan dan kebutuhan yang ditandai dengan munculnya rasa.

Berdasarkan pandangan diatas dapat dikatakan bahwa motivasi merupakan sebuah dukungan yang menyebabkan terjadinya perubahan karena adanya tujuan kebutuhan yang ditandai dengan munculnya rasa.

\section{Jenis-jenis Motivasi}

Motivasi tidak hanya berasal dari dalam diri melainkan dari luar diri seseorang dan bentuknya juga bermacam-macam. Sadirman dalam Amaludin (2012:11) mengatakan bahwa motivasi terbagi menjadi motivasi bawaan yang atau disebut motivasi dalam diri dan motivasi yang dipelajari yaitu motivasi yang berasal dari luar diri. Omar dalam Putri (2017:17-18) 
mengatakan motivasi terbagi kedalam dua jenis, yaitu motivasi intrinsic dan motivasi ekstrinsik.Motivasi intrinsik adalah motivasi peserta didik sebagai penggerak untuk melakukan sesuatu dengan keinginannya. Sedangkan motivasi ekstrinsik merupakan motivasi yang berasal dari luar diri peserta didik pada saat pembelajaran usai.

$$
\text { Belajar dan pembelajaran }
$$
merupakan satu kesatuan yang tidak bisa dipisahkan dalam sebuah pendidikan. Peserta didik, dianggap belajar apabila mereka sudah melalui tahap pembelajaran. hal ini dikarenakan pembelajaran merupakan sebuah proses bagi peserta didik untuk belajar. Suherman dalam Darmika (2017), mengatakan bahwa proses komunikasi dalam rangka perubahan sikap adalah pembelajaran. proses mengatur, mengorganisasikan, dan mendorong peserta didik melakukan proses belajar (Aprida, 2017). Trianto (2009:19) pembelajaran juga merupakan aspek kegiatan rinci dan usaha sadar seorang pendidik untuk membelajarkan peserta didiknya supaya tujuannya pembelajaran tercapai

Berdasarkan pendapat diatas pembelajaran merupakan proses kegiatan kompleks dengan upaya pemberian stimulus untuk mencapai perubahan sikap melalui komunikasi berupa pesan. Pesan dalam pembelajaran disebut ecoding yang berisi symbol komuni kasi verbal maupun non-verbal.

\section{METODE PENELITIAN}

Penelitian ini menggunakan rancangan deskriptif kuntitatif, jenis penelitian suvey. Penelitian ini dirancang untuk medeskripsikan Motivasi belajar peserta didik kelas VIII dalam mengikuti pembelajaran daring pada masa pandemic murni yang berasal dari dalam diri peserta didik pada saat proses pembelajaran yang bersumber dari kebutuhan dan tujuan COVID-19 di SMP Negeri 3 Banyuwangi tahun 2020/2021. Populasi dalam penelitian ini adalah seluruh peserta didik kelas VIII SMP Negeri 3 Banyuwangi dengan jumlah 235 orang.

Sementara sampel dipilih menggunakan teknik random sampling, pengambilan sampel dengan menetapkan subjek yang akan diteliti. Sampel dalam penelitian ini adalah $30 \% \times 235=70$, responden adalah jumlah sampel dalam penelitian ini yaitu 70 peserta didik kelas VIII SMP Negeri 3 Banyuwangi.

Berdasarkan pembahsan diatas metode pengumpulan data dala peneltian ini adalah metode kuesioner dengan memberikan angket kepada responden yang menjadi subjek dalam penelitian ini 70 peserta didik kelas VIII di SMP Negeri 3 Banyuwangi.

\section{HASIL DAN PEMBAHASAN}

Penelitian bertempat di SMP Negeri 3 Banyuwangi, Jl. Krakatau No. 37 Singotrunan, Kec. Banyuwangi, Kab. Banyuwangi. Waktu penelitian dan pengambilan data dilakukan secara daring melalui aplikasi google form yang diberikan kepada peserta didik pada hari Senin,14 Januari sampai dengan jum'at 25 Januari 2021. Faktor yang dianalisis agar mengetahui motivasi belajar peserta didik, yaitu unsur intrinsik dengan 4 indikator (kesehatan, perhatian, minat, dan bakat) dengan memuat 12 pernyataan dan unsur ekstrinsik yang terdiri dari tiga indikator metode mengajar, alat pelajaran, dan kondisi lingkungan dengan rincian 8 pernyataan, berikut adalah analisis data hasil penelitian 
Tabel 01 Hasil Analisis Deskriptif

\begin{tabular}{llcll}
\hline No. & Indikator & $\begin{array}{l}\text { Banyak } \\
\text { Peserta didik }\end{array}$ & $\begin{array}{l}\text { Rata- } \\
\text { rata }\end{array}$ & Katagori \\
\hline 1. & $\begin{array}{l}\text { Faktor } \\
\text { Instrinsik }\end{array}$ & 70 & 56,80 & Baik \\
\hline 2. & $\begin{array}{l}\text { Faktor } \\
\text { Ekstrinsik }\end{array}$ & 70 & 57,06 & Baik \\
& & & & \\
\hline
\end{tabular}

20 Pernyataan pada indikator intrinsik memperoleh skor $56,80 \%$, sedanglan pada 20 pernyataan indikator ekstrinsik mendapatkan skor 57,06\%. Angka tersebut bila dikonversikan dalam tabel skala penilaian kategori berada pada kategori baik, untuk mengetahui hasil analisis data pada kedua indikator pada variabel motivasi belajar peserta didik kelas VIII dalam mengikuti pembelajaran PJOK secara daring pada masa pandemic covid-19 di SMP Negeri 3 Banyuwangi.

Perhitungan jumlah skor rata-rata mottivasi peserta didik berdasarkan akumulasi pencapaian dan respon 70 responden terhadap 20 pernyataan dihitung menggunakan rumus sebagai berikut: Rumus :

$\begin{aligned}=\bar{x} & =\frac{\sum f}{n} \\ & =\frac{4.519}{70} \\ & =64,5\end{aligned}$

Berdasarkan hasil skala penilaian kategori penelitian ini berada pada kategori sangat baik.

\section{Pembahasan}

Dari 70 peserta didik dapat diakumulasikan bahwa sebanyak 43 peserta didik memberikan tanggapan sangat sangat baik, 23 peserta didik memberikan tanggapan baik, dan 4 peserta didik memberikan tanggapan cukup baik.

Skor rata-rata yang diperoleh dari hasil analisi data tersebut yakni 64,5 sehingga motivasi belajar pesertadidik kelas VIII dalam mengikuti pembelajaran PJOK pada masa pandemi covid-19 di SMP Negeri 3 Banyuwangi tahun 2020/2021 sudah dapat dikatakan sangat baik.

Hasil tersebut jika dikonvensikan pada tabel interval kategori, seluruh tanggapan peserta didik terhadap 20 pernyataan masuk pada kategori sangat baik, sehingga pembelajaran PJOK secara daring selama pandemi covid-19 mampu menumbuhkan motivasi peserta didik baik dari dalam (intrinsik) yakni perhatian, bakat, kesehatan, dan minat, maupun dari luar (ekstrinsik) yakni metode mengajar, kondisi lingkungan, dan alat pelajaran.

Hasil tersebut sejalan dengan pemrolehan yang dilakukan oleh Apip (2012), bahwa unsur intrinsik peserta didik dalam mengikuti pembelajaran olaharaga melalui aktivitas permainan kecil di SMPLB mampu mempengaruhi motivasi peserta didik berada pada kategori tinggi pada unsur ektrinsik yang dipengaruhi oleh tingginya kebutuhan fisikologis.

\section{PENUTUP}




\section{SIMPULAN}

Berdasarkan rumusan masalah, hasil penelitian, dan pembahasan, adapun simpulan penelitian motivasi belajar peserta didik kelas VIII dalam mengikuti pembelajaran PJOK secara daring pada masa pandemi COVID-19 di SMP Negeri 3 Banyuwangi, yakni dieperoleh skor rata-rata 64,5 . Hasil tersebut jika dikonvensikan pada tabel interval kategori, seluruh tanggapan peserta didik terhadap 20 pernyataan masuk pada kategori sangat baik.

\section{SARAN}

Adapun saran yang dapat diberikan adalah sebagai berikut :

\section{Bagi Guru POK}

Peneliti berharap, Guru dapat terus meningkatkan kualitas pembelajaran pada masa pandemi covid-19 dengan menjadikan penelitian ini sebagai salah satu tolak ukur untuk meningkatkan motivasi dan mengetahui kesiapan peserta didik dalam mengikuti pembelajaran PJOK secara

\section{DAFTAR RUJUKAN}

Amaludin, Apip. 2013. Survei Motivasi Belajar Siswa dalam Mengikuti Pendidikan Jasmani Melalui Aktivitas Permainan Kecil di SMPLB Manunggal Slawi Kab.Tegal Tahun 2012. Semarang: UNNES.

Darmika, I Putu. 2017. Penggunaan ELearning Dalam Pembelajaran Bahasa Indonesia di SMA Negeri Bali Mandara. E-Journal Jurusan Pendidikan Bahasa dan Sastra Indonesia Volume : Vol: 7 No: 2 Tahun:2017. Tersedia pada https://www.google.com/search?q= Penggunaan+ELearning+Dalam+Pembelajaran+B ahasa+Indonesia+di+SMA+Negeri +Bali+Mandara. (diakses pada 5 Oktober 2019) daring.

2. Bagi peserta didik

Peneliti berharap, peserta didik dapat mendukung dan memberdayakan segala aplikasi yang dimanfaatkan oleh guru sebagai media pembelajaran selama covid-19. Selain itu, peserta didik diharapkan dapat menjaga kesiapan belajar dengan terus memberikan motivasi terhadap dirinya sendiri baik melalui faktor ektrinsik atau intrinsik.

3. Bagi Sekolah

Peneliti berharap, sekolah dapat terus mengontrol system pembelajaran secara daring yang digunakan oleh guru dalam proses belajar mengajar pada masa pandemi covid-19 dan memberikan sarana prasarana memadai bagi peserta didik yang memiliki kendala media, seperti kuota dan hand phone.

4. Bagi peneliti lain

Penelitian ini tergolong ke dalam penelitian deskriptif kuantitatif. Maka, peneliti berharap, peneliti lain dapat membuat penelitian lanjutan dengan populasi dan variabel yang lebih luas, sehingga hasil yang diperoleh dapat menjadi sumbangan ide bagi penelitian yang lain.

Pane Fitrah, Aprida.2017. Jurnal Kajian IImu-ilmu Keislaman. Vol. 03 No. 2 Desember 2017.

Slameto. 2003. Belajar dan Faktor-faktor yang Mempengaruhinya. Jakarta: Rineka Cipta.

Sugihartono, dkk. (2007.) Psikologi Pendidikan, Yogyakarta: UNY Press.

Trianto. 2009. Mendesain Model Pembelajaran Inovatif- Progresif . Jakarta: Kencana.

Yuliana. 2020. Corona Virus Disease (Covid-19); Sebuah Tinjauan Literature. Volume 2, nomor 1 Februari 2020 